\title{
SKAM i skolen
}

\section{Av Christian Lomsdalen}

Jenta som flykter fra seg selv, gutten som er hemmelig forelsket $i$ bestekompisen, hun med spiseforstyrrelser, hun i hijab som ikke passer inn, han som røyker for mye marihuana, søsknene som har opplevd omsorgssvikt, hun flinke, og alle de andre.

ChRistian Lomsdalen, Lektor i samfunnsfag og religionsfag ved Metis videregående skole, konfirmasjonsleder.E-post: christian@lomsdalen.im

SKAM er på alles lepper, og har vel vært det i løpet av det siste året. Det er derfor uunngåelig at det vil vurderes å trekke serien inn i undervisningen. Hvis vi skal se bort ifra andre fag hvor serien også kan brukes, som naturfag, samfunnsfag, musikk, norsk og så videre, så er det tydelig at serien kan brukes til å ta opp temaer for å dekke kompetansemål i både Religion \& etikk og i KRLE. Jeg skal derfor se på hvilke temaer som serien tar opp som kan brukes i undervisningen i disse to fagene, og jeg skal se litt på hvorfor dette kan gjøres.

En av styrkene - og ett av problemene - med å bruke SKAM i undervisningen er at historiene som fortelles i serien, er forholdsvis realistiske. Vi har kanskje ikke møtt dem alle sammen ennå, men noen av dem har vi truffet - og fortsetter vi i denne jobben, så kommer vi til å treffe flere av dem. Dette kan også medføre at en del av sekvensene, historiene og skjebnene kan treffe litt for nært hos noen av elevene hvis vi viser dem. Samtidig kan vi forvente at de fleste av elevene allerede enten har sett eller kjenner til fortellingene - det vil ikke være første gangen de ser eller hører om dette.

\section{SKAM I UNDERVISNINGEN}

Det er liten tvil om at NRKs populære ungdomsserie SKAM kan brukes til å dekke eller innlede undervisning i forskjellige kompetansemål i KRLE-faget og i Religion og Etikk på videregående. Enten det handler om nyreligiøsitet, islam, kristendommen, eller emner som er plassert i bolken filosofi og etikk. Være seg nakenbilder, hvordan man skal være i et forhold, hijabbruk, utroskap, voldtekt, nyreligiøsitet, psykisk sykdom ${ }^{1}$, prostitusjon, ensomhet, eller en rekke andre temaer. Samtidig bør man spørre seg: gir videoklipp eller narrativene fra denne serien noen som helst læringsgevinst, og har det noen pedagogisk begrunnelse?

1 Se f.eks. http://www.aftenposten.no/meninger/debatt/Om-dere-tar-opp-bipolar-lidelse-for-a-fjerne-et-tabuVar-sa-snill_-Skam_-ikke-forsterk-det-forst-610560b.html og http://www.aftenposten.no/meninger/debatt/ Takk_-Skam_-for-at-dere-viser-at-det-ikke-trenger-vare-sa-ille-a-vare-bipolar---som-meg--Cathrine-Smith6106̆ 6 b.html 
På tross av at man kan påstå at SKAM til dels har blitt overtatt av voksengenerasjonen, ${ }^{2}$ bærer serien (og den transmediale formidlingsplattformen) preg av å være et fenomen skapt for ungdomsgenerasjonen. Om ikke annet har en stor andel av elevene på ungdomstrinnet og $\mathrm{i}$ videregående skole sett på serien. Det er en referanseramme - det er historier elevene kjenner og $\mathrm{i}$ stor grad har et forhold til. I SKAM møter elevene historier som gjør at de kan diskutere vanskelige temaer uten å måtte knytte det til sin egen person eller egne opplevelser. Dette gir elever som er usikre på sin egen identitet, sine egne meninger, eller på sine egne opplevelser en mulighet til å fremme sine tanker om temaet - som om det ikke angår dem selv, eller med en trygg avstand. Det dreier seg jo om Isak, Noora, Vilde, Eva, eller Sana.

\section{RELIGION I SKAM}

I $\emptyset$ kende grad gjennom sesongene ser det ut til at manusforfatterne har begynt å flette inn religion. ${ }^{3}$ Fra å bare være knyttet til Sana sin hijab eller noen kommentarer knyttet til muslimers syn på sex før ekteskapet eller helvete, kommer kristen tro mer inn som et element i serien i sesong tre - primært knyttet til oppfatninger om homofili4. Samtidig tar serien opp nyreligiøsitet for eksempel i ungdommenes eksperimentering med ouija-brett. Generelt er det derimot grunnlag for å si at serien fremstiller religiøsitet som noe som stort sett har en lav profil i ungdommenes liv, utenom enkelte bikarakterer med kort skjermtid som gir inntrykk av å være sterkt troende muslimer.

\section{SKAM I TIMEN}

Hvis vi ser bort ifra muligheten at man bruker klipp fra serien som interessevekkere i oppstarten av et tema, er det særlig som diskusjonsopplegg eller som utgangspunkt for skriveoppgaver jeg tenker og opplever at videosnuttene fra SKAM har et stort potensiale. Tidsmessig er et slikt opplegg relativt fleksibelt. Enten du velger å vise et to-minutters klipp før en diskusjon om man har 20 minutter til rådighet, eller et lengre klipp før det er både gruppediskusjon og plenumsdiskusjon om man har mer tid tilgjengelig. Dette gir gode muligheter til å bruke serien der det er relevant, selv om man har lite tid, men også når det er mye tid tilgjengelig.

Hver enkeltepisode er svært kort, og man finner de i dette formatet på P3

2 Se http://www.vl.no/meninger/kommentar/skams-suksess-hever-statusen-til-ungdomskulturen-1.722678 og http://www.dagbladet.no/2016/05/02/kultur/meninger/pa_kornet/skam/tv_og_medier/44080735/

3 Se innlegg om dette på http://www.vl.no/2.964/skams-religiose-flort-1.801935, http://www.vl.no/kultur/religiost-vendepunkt-1.901339 og http://www.vl.no/meninger/kommentar/o-helga-natt-har-fatt-ny-dimensjonetter-skam-1.905067

4 http://www.aftenposten.no/kultur/Kommentar-Hva-om-Isak-faktisk-liker-bade-gutter-og-jenter-605810b. html 
sine nettsider 5 . Samtidig så finner man de kortere klippene samlet i ukesepisoder på NRKs nett-tv. En serie over flere sesonger blir naturlig nok for lang, og derfor relativt uhåndterlig. Derfor har jeg til slutt i artikkelen lagt en oversikt over noen av de episodene jeg mener er særlig aktuelle for bruk i undervisning ${ }^{6}$. Her går jeg inn på de tematiske sidene ved episodene, men det er ikke gitt at andre er enige eller at jeg har fătt med meg alle temaene, men det er en start, og kan fungere som en slags tentativ temaguide til temaene som er tatt opp i hver episode. Slik kan det bli lettere å finne det klippet man trenger til undervisningen man skal legge opp til, eller temaet man skal diskutere.

\section{LFRERVEILEDET SKAM}

Et av spørsmålene som bør reise seg, er hvorvidt vi bør bruke denne serien overhodet. Det kan være at vi burde la ungdomskulturen være nettopp det, ungdomskultur. Samtidig gir dette et diskusjonsrom som åpner for deltagelse også på sensitive områder. Når serien samtidig tar opp såpass mange temaer og har så stor gjenkjennelse i elevgruppen, kan det være verdt å ta det med.

Ellers deler det å bruke denne serien $\mathrm{i}$ undervisningen problemstillinger med det å ta opp vanskelige eller tabu temaer i undervisningen ellers. Noen ganger hender det at elevene har historier i bagasjen som gjør at de reagerer ekstra sterkt på enkelte temaer - for eksempel kan den potensielle festvoldtekten av Noora være en slik situasjon. Selv for elever i ungdomsskolen, og med $\emptyset \mathrm{kt}$ sannsynlighet om den brukes på videregående. Det er dermed en fordel å kjenne klassen om man $\emptyset$ nsker å drøfte slik problematikk, siden dette minsker faren for at dette kommer overraskende. Allikevel kan aldri denne risikoen fjernes helt, da vi vet at svært mange aldri forteller noen om slike erfaringer 7 . Dette går også på temaer som spiseforstyrrelser eller det å være i skapet med sin skeivhet.

Ellers er det interessant at serien også tar opp spiritualitet og bruken av for eksempel ouija-brett. Her kan det tenkes at foreldrene kan kritisere at dette bringes frem i lyset. Dette er en praksis som ikke nødvendigvis er godtatt i alle miljøer eller hos foreldre fra alle religioner eller livssyn. Samtidig kan det sies at dette nok er den episoden som kan sies å være den mest fjollete episoden, og det er et spørsmål om den fremstiller denne typen (ny)religiøsitet på en god måte. Episoden $^{8}$ er nok enklere å bruke i forhold til det å mestre, spiseforstyrrelser, eller å tillegge religiøse mennesker magiske egenskaper ut ifra fordommer.

Selv har jeg foreløpig brukt SKAM relativt begrenset i egen undervisning. Både ut ifra et $\emptyset$ nske om moderasjon, ut ifra at jeg »oppdaget» SKAM ganske

\footnotetext{
5 http://skam.p3.no/

6 For en komplett liste over tema i alle episodene se: http://lektorlomsdalen.no/opplastet/skamoversikt.pdf.

7 https://www.regjeringen.no/contentassets/a0f79a10854045c68770c5408e2b3d66/nkvts_vold-voldtekt-2014.pdf

8 Episode 2:4: »Jeg visste det var noe rart med henne»
} 
sent, og ut ifra fagene jeg har i år. Det er lett å bli engasjert når man ser så mange scener, episoder og scenarioer som kan brukes til å eksemplifisere noe og danne basis for et opplegg. Når det har vært brukt i undervisningen i år, så har det vært for å danne basis for diskusjon rundt slutshaming og deling av nakenbilder'. Dette er temaer som jeg tenker er viktig å ta opp, og sistnevnte var for så vidt også en del av årets \#UKE6-opplegg fra Sex \& Politikk, uten at jeg har sett om de brukte dette klippet også ${ }^{10}$.

For å avslutte er det viktig å påpeke at det er viktig med en stram lærerstyring på et slikt opplegg som tar opp slike temaer. Fordi serien tar opp mange temaer på kort tid, så er det viktig at læreren begrenser hvilke klipp og hvor lange klipp som vises. Samtidig kan det være et poeng med stram ordstyring for å sørge for at diskusjonen holder seg til karakterene i serien og ikke blir krenkende for elevene som er med i diskusjonen eller går på skolen med elevene. Det er også et poeng at man prøver å holde diskusjonen på riktig tema om man ser seg nødt til å vise et klipp som tar opp flere temaer enn de man $\emptyset$ nsker at timen skal dreie seg om.

9 Episodene 1:8, 2:1 og 2:9.

$10 \mathrm{http}: / /$ sexogpolitikk.no/

SKAM - eksempler på utdrag til bruk i undervisning:

\begin{tabular}{|l|l|l|l|l|l|}
\hline Sesong & Episode & Tittel & Tema & $\begin{array}{l}\text { Kompetan- } \\
\text { semål KRLE }\end{array}$ & $\begin{array}{l}\text { Aktuelle } \\
\text { kompetan- } \\
\text { semål i R\&E }\end{array}$ \\
\hline 1 & 3 & $\begin{array}{l}\text { Vi er de største } \\
\text { loserne på skolen }\end{array}$ & $\begin{array}{l}\text { Vennskap, bytte sex mot } \\
\text { goder, russebuss, status, lover } \\
\text { og regler i islam }\end{array}$ & $\begin{array}{l}\text { Islam 3 og 4; } \\
\text { RelMang 3; FE } \\
2,4 \text { og 7 }\end{array}$ & RR 4, 5 og 7 \\
\hline & 4 & Go for it din lille slut & $\begin{array}{l}\text { Når kan man ha noen sovende } \\
\text { over, stjeling av alkohol fra } \\
\text { foreldre, hvordan være i et } \\
\text { vennskap, betale av alkohol } \\
\text { med kropp, kjønnsroller, } \\
\text { «slutty» }\end{array}$ & FE 2 og 7 & IS 4, 5, 6 og 7 \\
\hline & 8 & $\begin{array}{l}\text { Hele skolen hater } \\
\text { meg }\end{array}$ & $\begin{array}{l}\text { Utroskap (hvorfor måtte du } \\
\text { være utro fordi du trodde } \\
\text { jeg var det?), sosial paria, } \\
\text { rykter, «jævlig fitte», feminist, } \\
\text { slutshaming, «hva liker du?», } \\
\text { «hvem er du?» }\end{array}$ & $\begin{array}{l}\text { FE 7; seksua- } \\
\text { lundervisning }\end{array}$ & FEL 6 \\
\hline 2 & 4 & $\begin{array}{l}\text { Jeg visste det var } \\
\text { noe rart med henne }\end{array}$ & $\begin{array}{l}\text { Ånder, Ouija, nyreligiøsitet, } \\
\text { spiseforstyrrelser }\end{array}$ & $\begin{array}{l}\text { RelMang 1 og } \\
\text { 5, FE 7 }\end{array}$ & KR 2 og 6 \\
\hline
\end{tabular}




\begin{tabular}{|c|c|c|c|c|c|}
\hline & 8 & $\begin{array}{l}\text { Du tenker bare på } \\
\text { William }\end{array}$ & $\begin{array}{l}\text { Kontrollerende kjærester, } \\
\text { hvem er jeg?, endrer vi } \\
\text { meninger i et forhold?, hva } \\
\text { skal til for å være selvstendig?, } \\
\text { ærlighet, hvem er en god nok } \\
\text { kjæreste, hva er en god venn? }\end{array}$ & FE 7 & \\
\hline & 10 & Jeg skal forklare alt & $\begin{array}{l}\text { Å bo i kollektiv, »du vet du ikke } \\
\text { må klare alt i verden alene», } \\
\text { angst, snooking på andres } \\
\text { ting, kan kjærester sjekke, } \\
\text { hvordan snakke til voldtekt- } \\
\text { sofre, voldtektsmottaket, } \\
\text { barneporno, barnepornolov- } \\
\text { givning, hvordan er vi mot } \\
\text { kjærester som forteller om } \\
\text { vanskelige ting }\end{array}$ & $\begin{array}{l}\text { FE 7; seksua- } \\
\text { lundervisning }\end{array}$ & \\
\hline \multirow[t]{5}{*}{3} & 1 & Lykke til, Isak & $\begin{array}{l}\text { Marihuana, »pulbar», jenter } \\
\text { med kort hår ser ut som } \\
\text { gutter, hjemmealenefester, } \\
\text { «jeg visste ikke at det var en } \\
\text { greie å gå ned på chicks», } \\
\text { «jenter og gutter kan jobbe } \\
\text { sammen, i Norge så gjør vi } \\
\text { det» }\end{array}$ & $\begin{array}{l}\text { Islam 3; FE } \\
\text { 7; seksua- } \\
\text { lundervisning; } \\
\text { RelMang 2 } \\
\text { og } 3\end{array}$ & \\
\hline & 2 & Du er over 18 , sant? & $\begin{array}{l}\text { Burqa, hijab, niqab?, kan man } \\
\text { se på noen om de er homo?, } \\
\text { er du helt homo? }\end{array}$ & $\begin{array}{l}\text { Islam 3; FE 7; } \\
\text { seksualunder- } \\
\text { visning }\end{array}$ & \\
\hline & 5 & $\begin{array}{l}\text { Samme tid et helt } \\
\text { annet sted }\end{array}$ & $\begin{array}{l}\text { Hva kan man gjøre på en } \\
\text { pause?, religiøse foreldre, } \\
\text { komme ut, «Livet er bedre } \\
\text { uten psykisk syke folk rundt } \\
\text { meg», «Det betyr ikke at jeg } \\
\text { ikke er homo», «Jeg er ikke } \\
\text { sånn homo homo», Homohis- } \\
\text { torien } 101 \text {, hjemmealenefest, } \\
\text { guttehistorier, «Det er } 2016 \text {, } \\
\text { det er på tide å komme ut av } \\
\text { skapet» }\end{array}$ & $\begin{array}{l}\text { FE 7; seksua- } \\
\text { lundervisning; } \\
\text { Kris 1, 4, og } \\
\text { 5; Jødedom } \\
\text { 3; Islam 3; } \\
\text { Hindu 3; Budd } \\
\text { 3; Livssyn 3; } \\
\text { RelMang 3; }\end{array}$ & \\
\hline & 8 & Mannen i mitt liv & $\begin{array}{l}\text { Homofile kjærester. Komp- } \\
\text { iser møte kjæreste, religion } \\
\text { og homofili, kristendom og } \\
\text { homofili, religiøse foreldre, } \\
\text { frykt vs religion vs hat }\end{array}$ & $\begin{array}{l}\text { FE 7; Islam 3; } \\
\text { Kris } 3\end{array}$ & \\
\hline & 9 & Det går over & $\begin{array}{l}\text { Pårørende i psykiatrien, } \\
\text { psykisk sykdom, hvordan } \\
\text { hjelpe best mulig }\end{array}$ & FE 7 & \\
\hline
\end{tabular}

